\title{
Unregistered Traditional Bone Setting Practice in Aceh, Indonesia: A Problem that Need to be Solved?
}

\author{
Safrizal Rahman ${ }^{1,2 *}$ Azharuddin Azharuddin ${ }^{1,2}$, Amanda Yufika ${ }^{3,4}$, Rovy Pratama ${ }^{3 *}$ \\ ${ }^{1}$ Orthopedics and Traumatology Division, Department of Surgery, School of Medicine, Universitas Syiah \\ Kuala, Banda Aceh, Aceh 23111, Indonesia \\ ${ }^{2}$ Orthopedics and Traumatology Division, Department of Surgery, Dr. Zainoel Abidin Hospital, Banda Aceh, \\ Aceh 24415, Indonesia \\ ${ }^{3}$ Medical Research Unit, School of Medicine, Universitas Syiah Kuala, Banda Aceh, Aceh 23111, Indonesia \\ ${ }^{4}$ Department of Family Medicine, School of Medicine, Universitas Syiah Kuala, Banda Aceh, Aceh 23111,
}

Indonesia

safrizalrahman@unsyiah.ac.id.azharspbo_kspine@yahoo.com,amandayufika@gmail.com, rovy.pratama@unsyiah.ac.id,

\begin{abstract}
Little is known about traditional bone setting (TBS) practise in Aceh, Indonesia despite of its common utilisation. The aim of this study was to explore the characteristics of TBS practise in Aceh, Indonesia. Thirty-nine participants from ten regencies in Aceh were interviewed from January to December 2019. Most of the participants were male (82.1\%), and aged between 31-50 years old (79,5\%). Half of the participants were elementary school graduates (51,3\%). More than half (59\%) of participants had been practicing bone setting for 5-10 years, and many of them (48.7\%) used traditional massages combined with splints and herbal mixtures. None (0\%) of the participant obtained legal permission to practice bone setting. More than half (71.8\%) obtained the knowledge of TBS from their ancestral heritage, only one participant obtained it through apprenticeships. We concluded that TBS practices in Aceh were unregistered, and the practitioners were mostly untrained. There is a need to provide training and permits for TBS practise to ensure patients' safety.
\end{abstract}

Keywords: traditional bone setting; Aceh; Indonesia

\section{Introduction}

According to the World Health Organization, traditional bone setting (TBS) is defined as the health practices, approaches, knowledge, and beliefs in incorporating plants, animals, minerals, spiritual therapies, manual techniques and exercises, used singularly or in combination, to diagnose and treat fracture in human beings. Traditional bone setter itself is a lay practitioner who provides management of dislocations and fractures, mostly without having prior formal training (Worku N, 2019). The principles of traditional bone setting include giving suggestions and psychological support, repositioning, relaxation, fixation, even employing supersitition and supernatural power (Udosen A, 2009). Most traditional bone setters utilize only one method of treatment such as the use of certain herbs, splinting, and massaging (Alonge T,, 2004), however, in daily practices each of them might use different techniques and methods when treating patients. These techniques and methods were usually not acquired from formal trainings, but derived from experiences and observations received from their forefathers (Udosen A, 2009).

Traditional bone setting is a common alternative medicine practice in Indonesia, including Aceh, due to limited orthopaedic service in the country. For more than 250 million people, Indonesia only has 1.150 orthopaedic surgeons, make the ratio become 1:220.000 people, smaller to its neighbor Malaysia whose ratio was 1 orthopedic surgeon for 70.000 citizen[5]. Aceh, with around 5 million people, only have 14 orthopaedic 
surgeons who provide services in 6 out of its 23 regions (Health Imo, 2019). On the other hand, the number of traffic accidents in Indonesia is still considerably high (Mohammed A, 2019), not to mention its nature as a disaster-prone area. The need of traumatology service and the limited number of orthopaedic surgeons made people have no choice but to utilise TBS practise. The patient's condition was generally good and did not require hospitalization (Gani, 2021).

Prior studies suggested that the reasons for the preference of TBS includes cheaper price, easy accessability, quick service, and suggestions from friends and families (Worku N, 2019; Udosen A, 2009; Onyemaechi NO, 2015; Thanni L; 2000). Other reasons that encouraged people to utilise TBS are sociocultural beliefs, and fear of operation and amputation (Onyemaechi NO, 2015; Omololu AB; 2008). However, traditional bone setters lack basic knowledge of anatomy, physiology, radiology, and principles of infection prevention and control, results in high failure rates and complications (Onyemaechi NO, 2015). Acute compartment syndrome, non-union, mal-union, joint stiffness, contractures, chronic osteomyelitis, Volkmann's ischemic contracture, and gangrene are the common complications cited in previous studies (Owumi B, 2012; Abia RP, 2017; Omololu B, 2002). As most of traditional bone setters are not officially registered, patients could not do anything when such complications happen.

The existence of TBS is not completely threatening for orthodox medicine. In countries where orthopedic services are limited and expensive, TBS can help provide primary fracture care (Onuminya J, 2004). Prior study suggested to incorporate trained traditional bone setters in primary healthcare since it is more cost-effective, especially for lower and middle-income countries (Omololu AB, 2008). Trainings for traditional bone setters by orthopedic surgeons were proven effective to reduce complications (Onuminya JE, 2006), making it safer for the patients. Moreover, incorporating TBS into healthcare system will make it easier to control its practice as well as to reduce the chance for malpractice.

There have been many studies exploring the practice of TBS in African countries, but to our knowledge there is no such study in Indonesia yet, despite of high utilisation of TBS service in the country. Thus, we carried out this study to explore the characteristics of TBS practise in Aceh, Indonesia.

\section{Research Methods}

This is a descriptive study carried out in ten regencies in Aceh from January to December 2019. The data was gathered by interviewing traditional bone setters across Aceh, who were selected using a snow-ball sampling methods. As traditional bone setters were not registered, the best way to find them was by utilising this sampling technique. Subjects who were aged above 18 years old, were practicing traditional bone setting in Aceh, and agreed to be interviewed were included in this study.

A questionnaire derived from an extensive review of previous papers was utilized in the interviews. Information about the duration of practice, availability of practice permit, therapeutic methods, source of knowledge, and the utilisation of supportive medical assistance were proposed to the participants beside socio-demographic characteristics, which include sex, age, religion, formal education, and origin of regency where they practice TBS. 
Sex was devided into two catagories: male and female, and religion was also devided into two: muslims and non-muslims. Age was devided into four groups: 31-40 years old, 41-50 years old, 51-60 years old, and >60 years old. Formal education was defined as the completed formal education obtained, and catagorised into four groups: No formal education (either having no formal education at all or did not complete elementary school), elementary school, middle school, and high school.

Duration of practice was divided into three categories: $<5$ years, 5-10 years, and $>10$ years. Availability of practise permit was categorised into two: have and not have. Therapeutic methods were divided into three groups: the use of traditional massages, splints, and herbal mixtures; the use of incantations; and a combination of the two. Source of knowledge about bone setting were categorized into three groups: supernatural powers, ancestral heritage, and apprenticeships. The utilisation of supportive medical assistance was investigated by asking questions about whether or not the bone setters use supportive medical examination such as X-rays or medical treatment like pain killers or vitamins. Univariate analysis was employed to analyze the data.

\section{Results and Discussion}

\subsection{Results}

\section{a. Socio-demographic Characteristics}

In total, we interviewed 39 TBS in ten regencies in Aceh province. Demographic data of the study participants is presented in Table 1 .

Table 1. Socio-demographic Characteristics of Study Participants $(n=39)$

\begin{tabular}{lrr}
\hline Variables & Frequency $(\mathrm{n})$ & Percent $(\%)$ \\
\hline Sex & 32 & 82.1 \\
Male & 7 & 17.9 \\
Female & & \\
Age (years) & 15 & 38.5 \\
$31-40$ & 16 & 41.0 \\
$41-50$ & 6 & 15.4 \\
$51-60$ & 2 & 5.1 \\
$>60$ & & \\
Religion & 39 & 100 \\
Muslims & 0 & 0 \\
Non-muslims & & \\
Formal education & 6 & 15.4 \\
No formal education & 20 & 51.3 \\
Elementary school & 11 & 28.2 \\
Junior high school & 2 & 5.1 \\
Senior high school & & \\
Origin of regency & 5 & 12.8 \\
Banda Aceh & 4 & 10.2 \\
Aceh Besar & 3 & 7.6 \\
Sigli & 5 & 12.8 \\
Pidie Jaya & 6 & 15.3 \\
Bireun & 2 & 5.1 \\
Lhokseumawe & 4 & 10.2 \\
Aceh Jaya & &
\end{tabular}




$\begin{array}{lrr}\text { West Aceh } & 5 & 12.8 \\ \text { East Aceh } & 2 & 5.1 \\ \text { Langsa } & 3 & 7.6\end{array}$

Based on the table, we can see that most of the participants were male $(82.1 \%)$, and aged between 31-50 years old (79.5\%). Half of the participants were elementary school graduates $(51.3 \%)$ with only around $5 \%$ finished high school. All of the participants $(100 \%)$ in our study were Muslims.

\section{b. Characteristics of TBS Practise}

In addition to the socio-demographic characteristics, we also gathered information regarding TBS practice, as presented in Table 2.

Table 2. The characteristics of TBS practice in Aceh

\begin{tabular}{|c|c|c|}
\hline Variables & Frequency $(\mathrm{n})$ & Percentage $(c$, \\
\hline \multicolumn{3}{|l|}{ Duration of practice } \\
\hline$<5$ years & 6 & 15.4 \\
\hline $5-10$ years & 23 & 59.0 \\
\hline$>10$ years & 10 & 25.6 \\
\hline \multicolumn{3}{|l|}{ Practice permit } \\
\hline Have & 0 & 0.0 \\
\hline Not have & 100 & 100.0 \\
\hline \multicolumn{3}{|l|}{ Therapeutic methods } \\
\hline $\begin{array}{l}\text { Traditional massages, splints, and herbal } \\
\text { mixtures }\end{array}$ & 19 & 48.7 \\
\hline use of incantations & 7 & 17.9 \\
\hline Combined method & 13 & 33.3 \\
\hline \multicolumn{3}{|l|}{ Source of Knowledge } \\
\hline Supernatural powers & 10 & 25.6 \\
\hline Ancestral heritage & 28 & 71.8 \\
\hline Apprenticeships & 1 & 2.6 \\
\hline \multicolumn{3}{|l|}{ Utilisation of supportive medical assistance } \\
\hline Yes & 9 & 23.1 \\
\hline No & 30 & 76.9 \\
\hline
\end{tabular}

More than half (59\%) of participants had been practicing bone setting for 5-10 years. Most of the participants $(48.7 \%)$ utilized traditional massages combined with splints and herbal mixtures. None of the participants $(0 \%)$ had legal permit to practice bone setting. More than half (71.8\%) gained the knowledge of TBS from their ancestral heritage, only one participant said that he obtained his knowledge and skill through apprenticeships. Nine $(33 \%)$ out of 39 participants used supportive medical tools such as $\mathrm{x}$-rays, pain killers, and vitamins in their daily practice.

\subsection{Discussion}

Our study found that most participants utilised traditional massages, splints, and herbal mixtures in their therapy. Prior studies suggested that TBS practise often utilise certain herbs, splinting, and massaging (Onuminya J, 2004; Dada A, 2011), although in most African countries traditional bone and joint treatment is based on superstition (Udosen A, 2009) . Most of our participants did not utilise supportive medical assistance in 
their practice, as it also mentioned in prior study (Owumi B, 2012; Sina OJ, 2014). However, one study suggested that some TBS practitioners in Nigeria started to incorporate modern medicine into their treatment such as using radiological aids (Solagberu B, 2005).

From our findings we can see that none of the participants obtained a legal practice permit, despite had practising TBS for $>5$ years. The Indonesian Ministry of Health actually regulates traditional medicine practices by issuing practice permits, which can be applied through the provincial or district health office (Health I, 2003). This regulation aims to control traditional medicine practices (Abia RP, 2017), however, our finding suggests that the regulation might not yet been implemented strictly in Aceh, leaving the traditional bone setters with no control or monitoring. Without legal practise permit, the government cannot control the quality of TBS services, while patients cannot get protection in case of malpractice (Sina OJ, 2014).

From our study, we also found that only 1 out of 39 participants got formal training in bone setting, while the rests got their skills and knowledge from their parents or ancestors. As has been discussed in previous studies, TBS practitioners usually gain knowledge and skills from their ancestors (Udosen A, 2009), which reflects that the skills are generated from experience rather than evidence. This might potentially cause harm to patients. In some countries, the government has tried to reduce the harm providing some training for traditional bone setters (Omololu $\mathrm{AB}$, , 2008). It showed that formal trainings from doctors, particularly orthopedic surgeons, can reduce the complications, hence increase patients' safety (Onuminya JE, 2006).

A report by the WHO stated that one third of the population lacks access to essential medicines, therefore, the provision of effective and safe traditional medicine could be very helpful in increasing access to health care services (Traditional Medicine). Instead of confronting traditional bone setters, it is better to incorporate them into the health care system. Prior studies showed that as traditional bone setters more accessible for the community, their existence can help provide initial treatment for neuromusculoskeletal problems such as simple fractures or dislocation (Omololu AB 2008; Onuminya JE; 2006). Formal training for traditional bone setters is necessary to create a safe and effective TBS practice.

\section{Conclusion}

Unregistered TBS practise in Aceh is a problem that needs to be solved. In a limited orthopaedic service area like Aceh, traditional bone setters could potentially help providing basic trauma management in the community. However, they need to be trained and integrated into the health care system to ensure the quality of service given and patients' safety.

\section{Limitations}

Despite the enormous effort, this study has some limitations. First, the sample size is small, only 39 participants were interviewed. As traditional bone setters are not registered, it was so difficult to find our study participants. However, as this is the first study in the country, we believe that even the smallest informations matter. Second, is the use of purposive sampling method, which decreased the full representation of the findings. Since traditional bone setter is a specific job, and usually does not have specific signs, which makes it difficult to find them randomly, the utilization of snow-ball sampling method is the most suitable option. Last, due to the nature of a descriptive study, we could not 
explore our findings deeper. Thus, further studies, possibly qualitative ones, are suggested to be carried out as follow-ups.

\section{Declarations}

\section{Ethics approval and consent to participate}

Ethical clearance was obtained from the Institutional Review Board of the School of Medicine, Universitas Syiah Kuala. Study participants were provided with an informed consent form contained the study purpose, risks and benefits, and the voluntary nature of the study. The informed consents were signed by the participants prior to the interviews.

\section{Availability of Data and Material}

The data used in the study is available from the corresponding author on reasonable request.

\section{Funding}

The study was funded by Syiah Kuala University as a part of Research Funding for Faculty Members. The University has no role in study design, data collection, analysis, or interpretation of the data as well as in manuscript writing.

\section{Acknowledgements}

We would like to thank Syiah Kuala University for the research grant, which allowed us to carry out this study. We would also like to thank and appreciate all traditional bone setters who agreed to participate in this study and shared their experience with us.

\section{Consent to Publish}

Not applicable.

\section{Competing Interests}

The authors declare that they have no competing interests.

\section{Author's Contributions}

SR and RP involved in study concept, methods design, analysis, interpretation, and manuscript drafting. AA participated in interpretation of the findings. AY took part in manuscript writing.

\section{References}

Abia RP, Okeke HC, Eyoma OE: Review of Traditional Bone Setting in Calabar Metropolis, Cross River State, Nigeria. International Journal of Social Sciences 2017, 11(1):126-134.

Alonge T, Dongo A, Nottidge T, Omololu A, Ogunlade S: Traditional bonesetters in South Western Nigeria-Friends or Foes? West African journal of medicine 2004, 23(1):8184.

Dada A, Yinusa W, Giwa S: Review of the practice of traditional bone setting in Nigeria. Afr Health Sci 2011, 11(2):262-265.

Gani, A., and Zakaria, I. (2021). Bone Maturnity Delay in Congenital Hypothyroid. Budapest International Research in Exact Sciences (BirEx) Journal Vol (3) (1):1321. 
Health IMo: [The Decree of Indonesian Ministry of Health No.1076/MENKES/SK/VII/2003 on Traditional Medicine Practise]. In. Edited by Health IMo, vol. No.1076/MENKES/SK/VII/2003. Jakarta: Indonesian Ministry of Health; 2003.

Health IMo: [Data of human resources in Dr. Zainoel Abidin Hospital, Aceh] In. Indonesian Ministry of Health; 2019.

Mohammed A, Ambak K, Mosa A, Syamsunur D: A Review of Traffic Accidents and Related Practices Worldwide. The Open Transportation Journal 2019, 13:65-83.

Onyemaechi NO, Lasebikan OA, Elachi IC, Popoola SO, Oluwadiya KS: Patronage of traditional bonesetters in Makurdi, north-central Nigeria. Patient Prefer Adherence 2015, 9:275-279.

Omololu AB, Ogunlade SO, Gopaldasani VK: The Practice of Traditional Bonesetting: Training Algorithm. Clin Orthop Relat Res 2008, 466:2392-2398.

Owumi B, Jerome T: Yoruba Traditional Bonesetters: The Practice of Orthopaedics in a Primitive Setting in Nigeria. J Trauma 2012, 20(4):312-322.

Omololu B, Ogunlade S, Alonge T: The complications seen from the treatment by traditional bonesetters. West Afr J Med 2002, 21(4):335-337.

Onuminya $\mathrm{J}$ : The role of the traditional bonesetter in primary fracture care in Nigeria. $S$ Afr Med J 2004, 94(8):652-658.

Onuminya JE: Performance of a Trained traditional Bone Setter in Primary Fracture Care. South Africa Medical Journal 2006, 96:320-322.

Red: [Indonesian Orthopaedic Association: The number of orthopaedic surgeons in Indonesia is still very few]. In: Suara Merdeka. Suara Merdeka; 2019.

Sina OJ, Taiwo OC, Ayodele IM: Traditional bone-setters and fracture care in Nigeria. Merit Research Journal of Art, Social Science and Humanities 2014, 2(6):074-080.

Solagberu B: Long bone fractures treated by traditional bonesetters: a study of patients' behaviour. Trop Doct 2005, 35(2):106-108. Thanni L: Factors influencing patronage of traditional bone setters. West Afr J Med 2000, 19(3):220-224.

Traditional Medicine: Overview [https://http://www.afro.who.int/health-topics/traditionalmedicine].

Udosen A: Basic Principles of Emergency Management of Acute Trauma. Calabar, Nigeria: Promiscom Konceots Publishers; 2009.

Worku N, Tewelde T, Abdissa B, Merga H: Preference of Traditional Bone Setting and associated factors among trauma patients with fracture at Black Lion Hospital in Addis Ababa, Ethiopia: institution based cross sectional study. BMC Res Notes 2019, 12(590). 